\title{
Promoting Education for Sustainable Development in Teacher Education integrating Blended Learning and Digital Tools: An Evaluation with Exemplary Cases
}

\author{
Chee Keong Chin ${ }^{1 *}$, Hairiah Munip ${ }^{1}$, Ryohei Miyadera ${ }^{2}$, Ng Khar Thoe ${ }^{3}$, Yeang Soon Ch'ng ${ }^{4}$, \\ Natthasurachet Promsing ${ }^{5}$ \\ 1 Teacher Education Institute Malaysia, Tuanku Bainun Campus, MALAYSIA \\ ${ }^{2}$ Kwansei Gakuin High School, JAPAN \\ ${ }^{3}$ SEAMEO RECSAM, MALAYSIA \\ ${ }^{4}$ Penang Free School, MALAYSIA \\ ${ }^{5}$ Rakmae Phomuang School, THAILAND
}

Received 4 April 2018 - Revised 21 June 2018 - Accepted 17 September 2018

\begin{abstract}
In the advent of digital era, the integration of technology-enhanced teacher education has been given emphasis along with raising awareness on Sustainable Development Goals (SDG). This article reports two case exemplars on the delivery of blended-mode curriculum to promote 'Education for Sustainable Development' (ESD) through training courses incorporating different strategies with the intention of providing students with more varieties of experiences related to learning science and mathematics. Facebook and Edmodo were used independently in different learning contexts. Students in the first case exemplar developed critical thinking skill as they justified their opinions in issues raised on Facebook. For hands-on experience, students planned and implemented various sustainability projects in primary schools. Students reported that the revised curriculum delivery strategies based on existing curriculum content helped to prepare them to teach sustainability in the future. In the second case exemplar, teachers were trained in Mathematics digital tools for teaching mathematics and subsequently employed critical thinking when they tried to make origami paper cups with the largest possible volume. In conclusion, technology-enhanced courses on sustainability should be integrated more regularly in both pre- and in-service teacher education to reaffirm the role of teacher as a vehicle of social change in sustainable development.
\end{abstract}

Keywords: education in sustainable development, curriculum delivery, Facebook, Edmodo, teaching and learning strategy

\section{INTRODUCTION}

Preparing future teachers and providing enrichment for in-service teachers to be competent in teaching children about issues on sustainability has often been undervalued. However, with the availability of technology, the delivery of pre-/in-service teacher education or training courses can be transformed into blended learning mode to enhance face-to-face lecture and hands-on learning experience on digital learning platforms to promote critical discussion and sharing of ideas and personal experiences. In the advent of digital era, the integration of technologyenhanced teacher education has been given emphasis along with raising awareness on Sustainable Development Goals (SDG). This article reports case exemplars on the delivery of blended-mode curriculum to promote 'Education for Sustainable Development' (ESD) through pre-/in-service training courses.

(C) 2019 by the authors; licensee Modestum Ltd., UK. This article is an open access article distributed under the terms and conditions of the Creative Commons Attribution License (http://creativecommons.org/licenses/by/4.0/). 《kevincck19@gmail.com (*Correspondence) $\square$ hairiahmunip@yahoo.com $\square$ runners@kwansei.ac.jp 


\section{Contribution of this paper to the literature}

- This paper illustrates how digital social media can be used to support education for sustainable development (ESD) in Malaysian pre-service teacher education to bridge face-to-face classroom interaction and out-of-classroom learning experience.

- Curriculum delivery methods were revised to include instructional strategies such as lectures, pre-service teachers' presentation, sustainability projects and games to suit the different topics in the course to promote 'Conservation and Wise Use of Resources'.

- Digital tool was also leveraged in providing professional development training for in-service mathematics teachers to promote critical thinking.

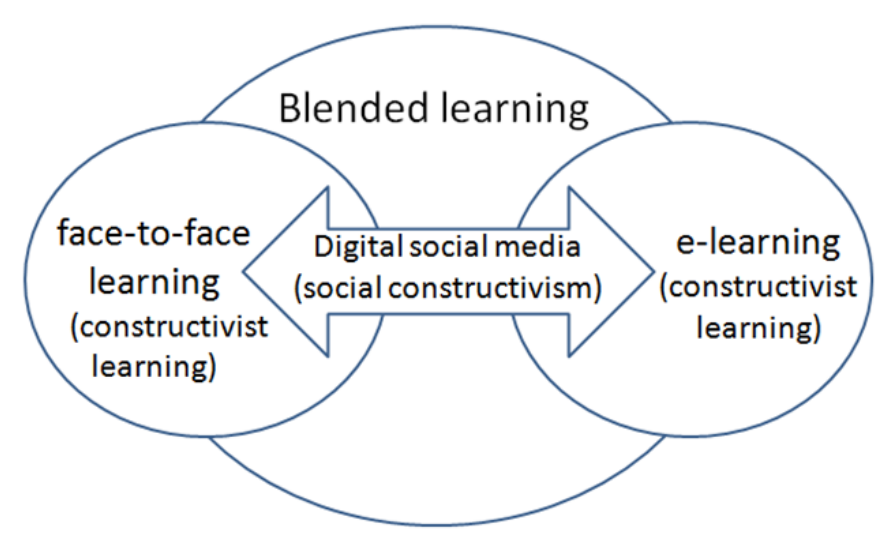

Figure 1. Theoretical framework of blended learning

\section{Background and Review of Related Literature}

The concept of sustainable development is based on an integrative view of intertwining economic, social and environmental dimensions. The Sustainable Development Goals (SDG) committed by governments in 2012 during the United Nations Rio+20 summit in Brazil can be considered the culmination of extended debate and another milestone-setting in human endeavour to address a broad range of social, economic and development issues. Education can be an effective mean of social change for two important reasons (Sterling, 2016). Firstly, education has the potential to enhance the effectiveness of other means of implementation by developing informed engagement, empowerment of stakeholders and cultivation of their creativity and enthusiasm. Secondly, education can leave a lasting change as stakeholders have the ownership of the change, in contrast to other means of implementations such as policy, monitoring, incentives and legislation which are effective only when they are in force.

Despite the challenge of reaching a consensus of what constitutes blended learning, Bonk and Graham (2006) had summarised the most common understanding of blended learning as combination of instructional modalities, learning theories, pedagogical dimensions and technologies. More broadly, blended learning is also understood as integration of face-to-face learning with e-learning. The theoretical framework for the present study is derived from this broadly termed blended learning in which social media platform such as Facebook and social learning platform such as Edmodo were used to bridge the face-to-face learning of the pre-service teaching with e-learning (Figure 1). Combination of face-to-face learning modality mainly by lectures project-based learning with e-learning through posted documents and linked websites provided pre-service teachers the learning opportunities that were constructivist in nature in which learners were actively constructing their own knowledge by engagement in reallife situations (Steffe \& Gale, 1995). As pre-service teachers interact with both face-to-face learning and e-learning materials and participated in sustainability projects in schools, they were actively constructing and expanding their personal knowledge based on connectivism learning theory which examines the creation of knowledge in a digitally-enhanced society. Connectivism believes that knowledge is continually expanded as learners make novel connections to make new interpretations and understandings (Starkey, 2010).

While constructivist learning paradigm assumes that learning could occur as a result of individual interaction with learning material, social constructivism carries the notion that learning is socially situated as learners improve their knowledge through discussion, sharing and interaction with others (Vygotsky, 1978; Wengler 1998). This sociocultural perspective to learning asserts that learners confirms their experiential reality by interaction with others and are curious to know what others think as well. In the context of this study, social media and social 
learning platforms were integrated as part of learning experiences to form a cultural apprenticeship when preservice teachers have discussion, share ideas and provide feedback among each other and with lecturer. Without blending learning mode, most learning would have occurred in isolation as classroom interaction duration was only two weeks before these pre-service teachers were posted to different schools for practicum in the following 12 weeks. The blended learning theoretical framework of this study therefore can be viewed as a combination of faceto-face learning and e-learning which integrates constructivist and sociocultural learning theories embedded in various instructional modalities.

Blended learning holds the potential as an effective educational approach for teaching sustainability. This mode of learning comprises thoughtful integration of face-to-face with online learning experiences. This approach to learning entails disruptive teaching and learning dynamics as a result of reconceptualisation of contextual needs and other contingencies such as discipline, lesson development and resources required (Garrison \& Kanuka, 2004). Asynchronous Internet communication facilitates students to confront ideas or issues more objectively and reflectively as compared to synchronous face-to-face interaction, possibly due to better focus on the issues of discussion and less noise from face-to-face interaction. Additionally there is permanent record and expanded time in Internet discussion that encourages more thoughtful, reasoned and evidential discussion (Meyer, 2003). On the digital interface, the required writing skills provide the opportunity for students to express themselves in written texts. A review of studies by Heterick and Twigg (2003) revealed that there was increase in course completion rate, improved retention and improved student satisfaction with this mode of instruction. Blended learning of out-ofschool field trip on Moodle improved student engagement and resulted in positive correlation between their motivation for collaborative learning and academic achievement (Coll \& Coll, 2017).

Facebook, a Web 2.0 application is common online platform used for both social and educational purposes. A wide range of tools and applications in Facebook allow users to communicate and share information such as adding photos, videos, comments and links, allowing integration with other websites and other mobile applications (Brandtzaeg \& Heim, 2007). Research had shown that Facebook helps teachers to be more creative in teaching, and subsequently improved students' learning outcomes (Siraj, Azman, \& Hussin, 2013). Facebook functions as a portal for teachers to share broad range and complex learning materials such as links to videos and digital access to relevant websites (Davis, 2009).

Edmodo is another Web 2.0 application specifically designed for education to make learning more inclusive with parents, teachers and students participation. This learning platform could help teachers to manage online classes easily with features that facilitate students submitting assignments, receiving teacher feedback and alerts as well as voting on polls (Jarc, 2010; Witherspoon, 2011). Other features such as icons and badges improved students' motivation to perform better. Students also preferred to take online quiz on Edmodo as they could get immediate answer at the end of the quiz (Balasubramaniam et al., 2014). Rather than acting as a source of knowledge, Edmodo supported teachers as mediator or moderator in learning as student engagement in complex discussion was enhanced with Edmodo discussion board (Holland \& Muilenburg, 2011).

\section{Rationale and Research Objectives}

This paper reports two case exemplars on the delivery of blended-mode curriculum to promote 'Education for Sustainable Development' (ESD) through training courses incorporating different strategies. The study was undertaken to fulfil the following aims:

- To revise the curriculum delivery method to incorporate the use of digital tools with assessment on effective use of blended-learning platforms for environment education.

- To evaluate blended-mode learning activities for preparing teachers for teaching sustainability.

- To report on exemplary cases in which digital tools and e-platforms can be leveraged on to promote ESD and SDGs with enhanced thinking and technology skills.

The first case exemplar examines a teacher preparatory course which was modified to incorporate digital learning platform in blended learning mode to prepare student teachers for teaching sustainability learning in primary schools. The general aim of this course was to help students to gain the knowledge and skills in management of the environment which can be applied in school as well as daily lives. At the end of the course, students were expected to be able to explain the concept of sustainable development, to elaborate how environmental issues could be solved based on local contexts and to summarise and present sustainable living practices. The course comprised four topics to help students understand the historical development of education for sustainable development. Various UNESCO documents were used as part of course content to compare the different perspectives, practices and challenges of environmental education in different regions/countries around the world. In a separate topic they studied the impact of human activities on the environment and local issues related to environmental degradation resulted from human development activities. In the topic on education strategies, students were exposed to different strategies on teaching sustainability in school. 
The second case exemplar examines an in-service training workshop incorporating digital tool (e.g. Mathematics) and blended learning platform (e.g. Facebook) to prepare in-service mathematics and science teachers for teaching sustainability with enhanced thinking and technology skills among participants.

\section{METHODOLOGY}

Two case exemplars are reported in this study using qualitative research methods that require a keen sense of observation, awareness and sensitivity of researcher to conditions which might be relevant to the phenomena being studied. Each case study is an ethnographic inquiry of cultural practices in two learning institutions being studied involving purposive sampling with triangulated findings from multi-sources of evidences using mix-mode of data analysis. These include observations, interviews, documentary analysis of observation notes of lessons, and survey instrument with open-ended responses, often in computerized form and personal records (e.g. journals, video or tape-recording, still photographs). The findings were reported as problem-centred single case or phenomenon to gather information about the situation so that researchers could make interpretations of data and observations (Yin, 1994).

Case study has a distinctive place in evaluative research incorporating explanatory (learning processes) or exploratory (discovery in context) purposes (Yin, 1994). This approach was used as researchers were interested to evaluate their involvement in promoting ESD in teacher education programmes integrating blended learning and digital tools. In its simplest form, it is a basic design that can accommodate various disciplinary and philosophical perspectives involving an investigator making a detailed examination of a single subject, group or phenomenon, in what Cronbach (1982) termed as 'interpretation in context'. By concentrating on a single case/entity or phenomenon, the approach aimed to discover the interaction of significant factors which are characteristics of a phenomenon and help develop an in-depth understanding of it (Sarmiento, 2005).

The necessary permission has been obtained from relevant school authorities for the sustainability project to be conducted in schools.

\section{Case 1: Education for Sustainable Development course for Pre-service Teacher Participants and Intervention Activities}

The participants in the first case exemplar were 10 students who were enrolled in a sustainable development course in their degree programme to prepare them to be science teachers.

Prior to the beginning of the semester, the official document for course content, course learning outcomes, contact hours, content delivery and assessment methods were studied for preparation of coursework assignment. There was a need to redesign the delivery method of the curriculum to be more student-centric as well as contextual and experiential in nature. Lectures were given during the first two weeks of the semester before they were posted to primary schools for a 12-week practicum. UNESCO documents related to the course such as 'Review of Contexts and Structures for Education for Sustainable Development 2009' (UNESCO, 2009), and 'Education for Sustainable Development Sourcebook' (UNESCO, 2012) were posted in a Facebook group dedicated for this course. Guiding questions were posted to guide students to study these documents. Relevant links for reference such as 'The four pillars of learning' (accessed at http://www.unesco.org/new/en/education/networks/globalnetworks/aspnet/about-us/strategy/the-four-pillars-of-learning/) and Malaysia one of 12 mega biodiversity countries in the world' (accessed at https:// bigcatrescue.org/malaysia-one-of-12-mega-biodiversity-countries-inthe-world/) were also posted in the group. Students' participation in discussion on Facebook group was monitored and analysed.

Instead of learning the different strategies for teaching sustainability by lecture, the students were required to plan and carry out a sustainability project in the their respective school during the 12-week practicum in primary schools. It was essentially a project-based learning in which they had to discuss their project with the school teacher and produced a proposal to justify their chosen project and implement the project under the guidance and supervision of school teacher. Their on-going project was monitored on-site during supervisors' school visits. When the students returned from their 12-week practicum, they presented the outcome of their project as part of assessment. Pictures of their projects were shared on Edmodo so that they could obtain feedback and learn from each other. Each student signed up a student Edmodo account and joined an Edmodo class opened for this course. At the end of the course, students provided feedback on their learning experiences in a survey. They also responded to how the course has prepared them to teach sustainability in school.

\section{Case 2: Digital Tool Training for In-service Mathematics/Science Teachers}

For the second case exemplar, the in-service mathematics/science teachers were introduced with digital tools for mathematics teaching (Figure 2) that promotes thinking skills through activities that exemplify the practice of 


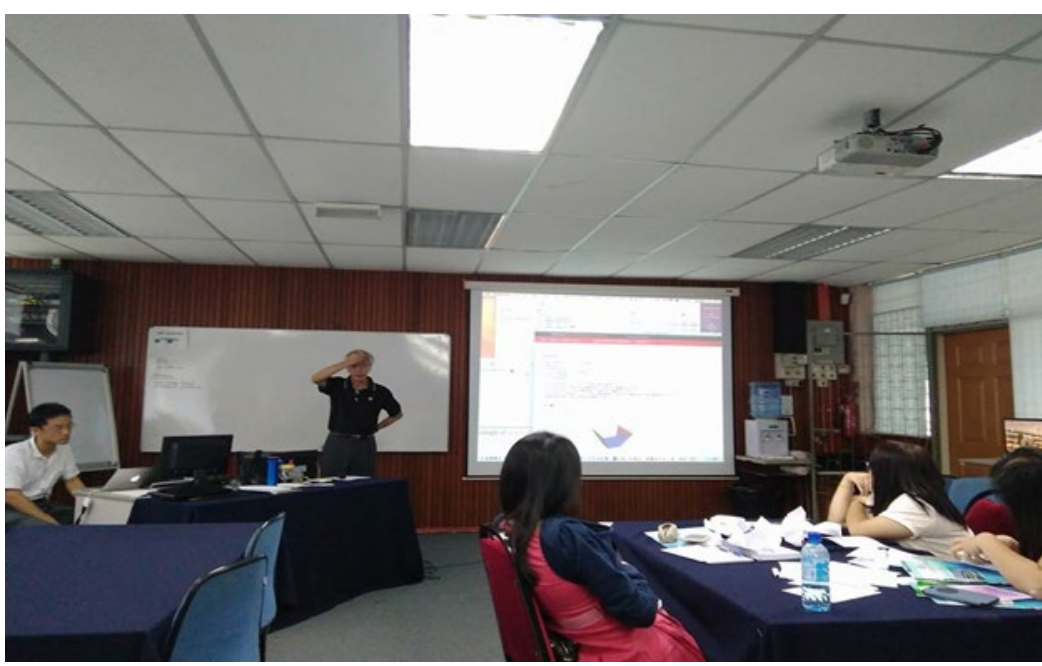

Figure 2. In-service training workshop on use of Mathematics digital tools

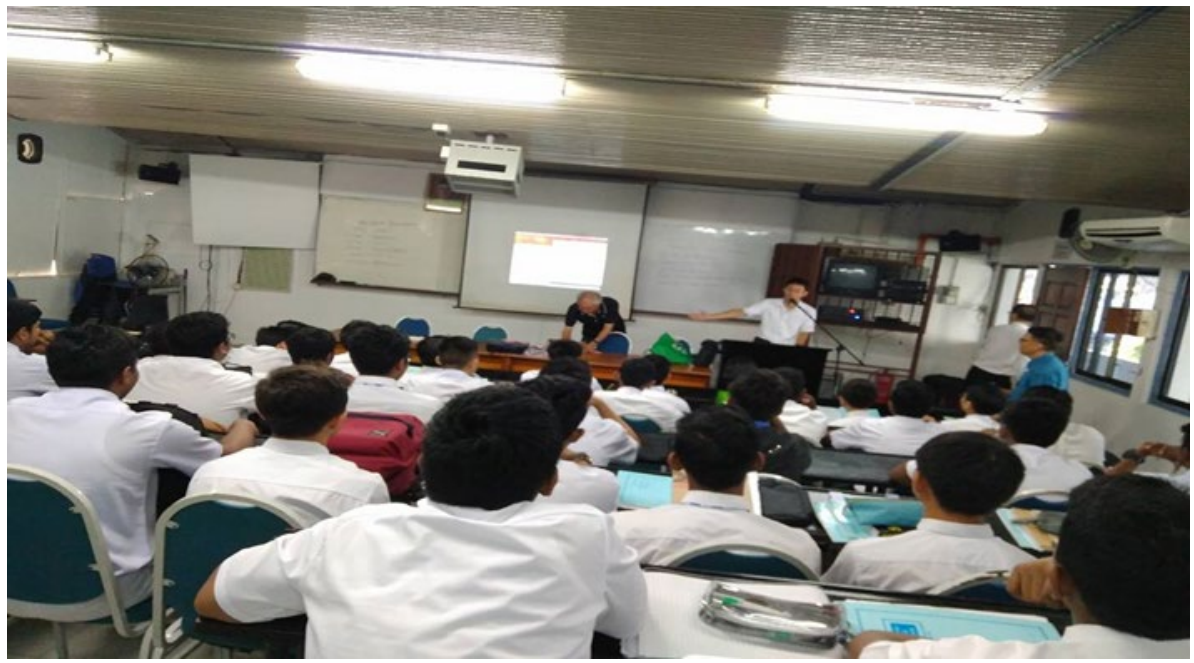

Figure 3. School visit with demonstration of Mathematics digital tools

'Conservation and Wise Use of Resources'. School visit was made with demonstration of digital tools among secondary students (Figure 3). Facebook was used as the main social learning platform during and after the training course.

\section{ANALYSIS AND DISCUSSION OF FINDINGS}

\section{Case 1: Evaluation on Learning Output of ESD course for Pre-service Teachers}

\section{Revision of curriculum delivery methods}

The teaching strategies mentioned in the curriculum standard document were lecture, tutorial and presentation without specific links to any particular topics. These strategies were thought to be severely insufficient to prepare the students with the skills of teaching sustainability in primary schools. After analysing the content of each topic, a revised curriculum delivery approach was produced to provide students with hands-on experience on teaching sustainability (Figure 4). The revised approach included other strategies such as carrying out sustainability projects in school as well as designing sustainability games. Altogether four delivery methods (lectures, carrying out school projects, designing games and presentation) were linked to specific topic based on the relevance of the methods to the content of each topic. Curriculum content was delivered based on the revised teaching and learning strategies. To enhance knowledge sharing and interaction between students who were posted to different schools, two digital platforms were used to facilitate the learning process. Facebook was used to post lecture materials and promote 


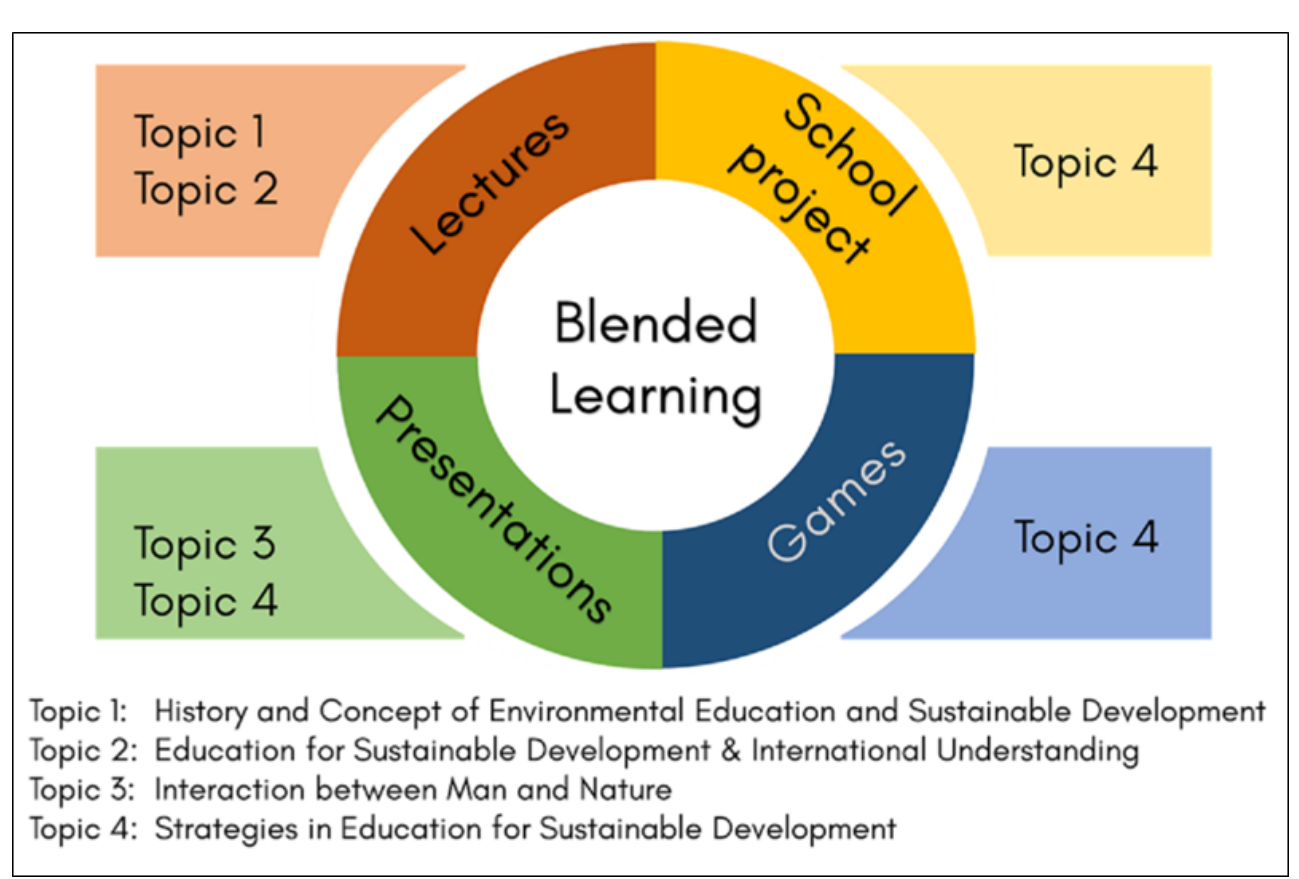

Figure 4. Revised strategies in delivery of curriculum for teaching sustainability

Table 1. Students' response to teaching and learning strategies

\begin{tabular}{|c|c|c|c|c|}
\hline \multirow[b]{2}{*}{ Teaching \& Learning Strategies } & \multicolumn{4}{|c|}{$\%$ of response } \\
\hline & $\begin{array}{l}\text { I learnt nothing } \\
\text { from this strategy }\end{array}$ & $\begin{array}{c}\text { This strategy } \\
\text { improved me a little }\end{array}$ & $\begin{array}{c}\text { This strategy was } \\
\text { effective }\end{array}$ & $\begin{array}{c}\text { This strategy was } \\
\text { very effective }\end{array}$ \\
\hline Lectures & & & 29 & 71 \\
\hline Presentation (environmental issues) & & & 43 & 57 \\
\hline Presentations (religion \& sustainability) & & & 43 & 57 \\
\hline School sustainability project & & & 43 & 57 \\
\hline Sustainability Games & & & 29 & 71 \\
\hline
\end{tabular}

discussion in the study of UNESCO documents whereas Edmodo was used to share pictures and information of sustainability projects carried out in each school.

At the end of the course, students responded in a survey on the different teaching and learning strategies they had experienced. All the four strategies were found to be effective in delivering the content of the curriculum (Table 1). Lectures on concepts of ESD by studying UNESCO documents supported by use of Facebook for online discussion was found to be very effective in helping students to understand and analyse the lengthy UNESCO documents. Sustainability games were also very effective in helping students to gain ideas and devise their own games to teach sustainability the fun way in school.

\section{Facebook as learning platform by sharing of experience and discussion on lecture notes}

Interestingly, the first post by students in the Facebook group for this course was sharing of personal experience of one student who recalled drawing a poster on sustainable consumption when she was in senior high school (Figure 5). During class discussion, she confessed that she had no idea what sustainable consumption was all about and she was drawing according to her teacher's instruction. Such phenomenon is a timely reminder for environment educationist on the ill-fated outcome of environmental education projects or activities which was carried out with tangible outcome i.e. a poster that seemed to depict sustainable consumption but actually failed to instil the awareness, knowledge and skills on sustainability. 


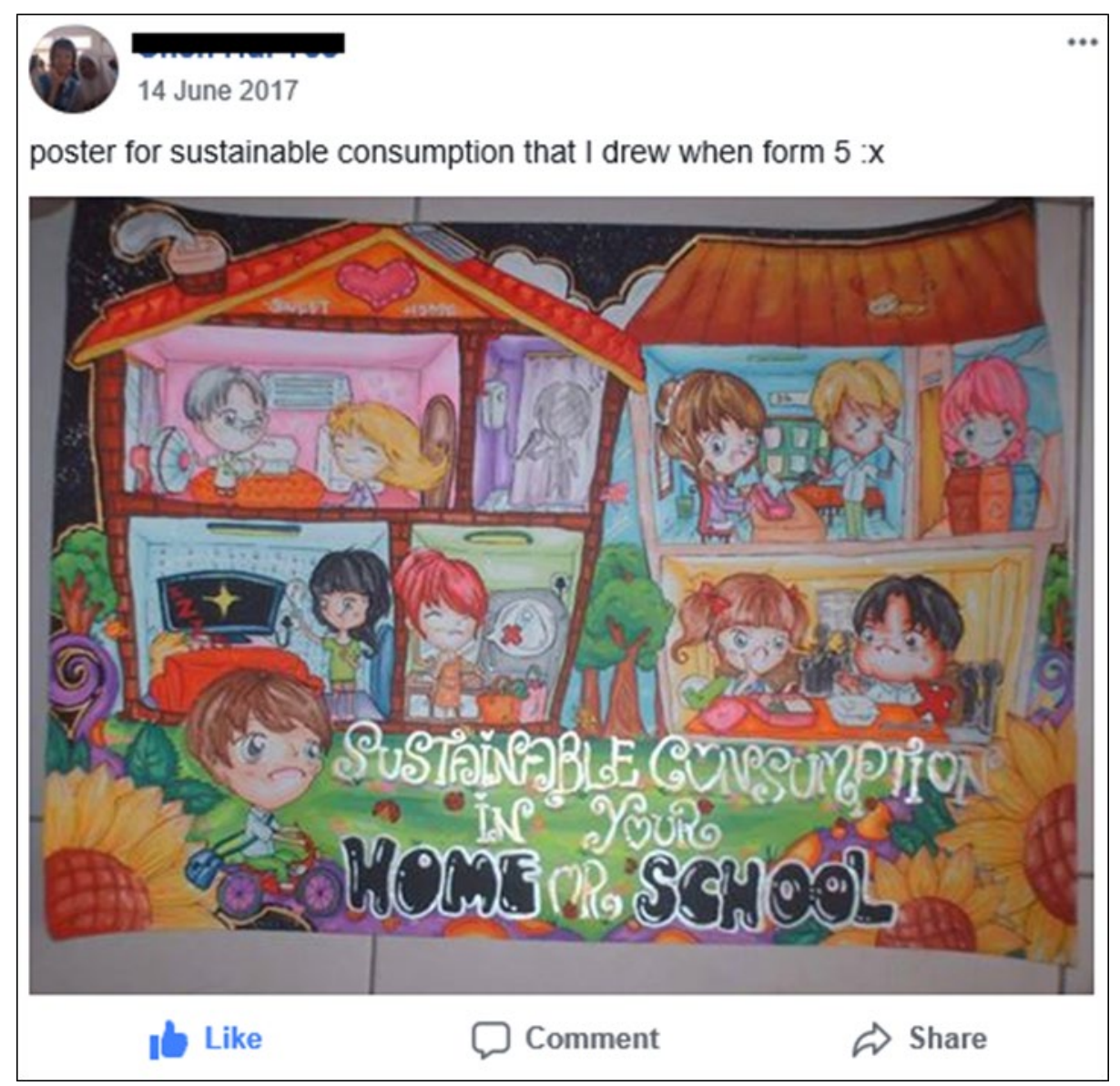

Figure 5. Sharing of personal experience on Facebook

Lecture notes were uploaded on Facebook prior to face-to-face lectures in class. During lectures, key ideas were delivered but students had to spend time beyond face-to-face lecture to study various UNESCO documents that were either posted as pdf files or linked to online source. Initially, there was no response from students when they were supposed to study the necessary learning materials beyond face-to-face lecture time and share their feedback on Facebook (Figure 6). However, students' response improved tremendously when specific questions were posted to guide students to study the learning materials (Figure 7). Out of 10 students, eight of them responded to at least one of the 13 questions posted. Two of the students even uploaded answers to all the 13 questions as Word documents in the Facebook group. 


Chin Chee Keong uploaded a file.
21 June 2017
EIU UNESCO.pdf
PDF
Download Preview Upload Revision
Write a comment...

Figure 6. No response from students on learning materials shared on Facebook

Chin Chee Keong 7. What are the common challenges to SD across different regions of the world?

Like $\cdot$ Reply $\cdot 41 w$

(2) Conflicts along the lines of ethnicity and religion, gender disparity in access to equal education, marginalization of ethnic minorities and rampant corruption among government officials and public servants.

Like - Reply - $41 w$

6 Economic, social and environmental issues

Like - Reply - $41 w$

Figure 7. Students posted answers for discussion when prompted with specific questions

Students also demonstrated that they could response to questions that require critical thinking skills. They were able to articulate their opinions clearly and justify their view based on the options presented to them. Students' responses to Questions 6 and 11 posted on Facebook were used to illustrate their critical thinking skills.

Question 6

Based on the list of challenges in education for sustainable development in Asia Pacific regions (pg 18), which one(s) do you think is/are the most pressing in Malaysia? 
Of all the problems stated that exist in the Asia Pacific regions, I think the most pressing issue in Malaysia is rural and remote areas, in particular small island nations, are often faced with marginalized populations and more expensive delivery of services. This is very apparent especially in East Malaysian states of Sabah and Sarawak. Some of the remote places are only accessible by boats or helicopter due to the lack of paved roads. Besides, the rural tribes do not get the same equal opportunity to quality education like those in the cities.

Response N6

"Ethnic, religious and linguistic barriers resulting in migration, lack of citizenship, human rights issues and conflict" is most pressing in Malaysia; since society in Malaysia is the form by many difference ethnic (Malays, Chinese, Indian ... ) which is the result of migration happened century ago, so we cant deny still culture clash is happen...

Response Y6

Responses N6 and Y6 for Question 6 indicated that these students were able to evaluate the list fo challenges in education for sustainable development in Asia-Pacific region and select the challenge that is relevant to the local context. Response N6 implied that the challenge would be geographical barrier in rural and remote areas of Borneo states which hinder quality education. On the other hand, Y6 justified that 'ethnic, religious and linguistic barriers' due to diverse multi-cultural backgrounds which could affect education for sustainable development in Malaysia.

Question 11

Justify which view do you think best represent the relationship between Environmental Education (EE) and Education for Sustainable Development (ESD)?

I support the second type of relationship between EE and ESD which is happening in countries, where the government has joined the international group of nations that committed themselves to ESD, groups are strategically or pragmatically adopting ESD, without necessarily changing their EE practice in order to remain eligible for funding and government support. This is because I think the cooperation between government and private entity is very crucial to enhance the quality of Education for Sustainable Development.

Response N11

In my opinion, the third interpretation best describe the relationship between EE and ESD as both programs are distinct but do overlap each other. EE refers to a form of education where we were taught about how the environment function, and its relationship with human beings while ESD concentrates on empowering individuals to make decisions which leads to sustainability and social justice. Both fields are related to each other as they are all related to environmental issues and how the human community is able to protect it.

Response W11

Question 11 was another open-ended question with no definite answer. There were three different perspectives on the relationship between Environmental Education and Education for Sustainable Development. Students argued for their choice of perspective by providing reasons to support their view. Student N11 supported the second perspective in which EE is viewed as part of ESD. N11 justified that this is important to protect the existing efforts in EE which narrowly focuses on environmental protection and nature conservation, while at the same time embracing the larger concept of ESD which encompasses socio-economic, political and cultural dimensions to garner funding from government agencies as well as private entities. On the other hand, student W11 opined that the third perspective of EE and ESD was more relevant to present EE and ESD as distinct programmes with overlapping areas of interest. While EE focuses on educational aspects and ESD gives attention to social responsibilities, both are committed to empowering human community to protect the environment.

\section{School sustainability projects shared on Edmodo}

Altogether nine projects were carried out in seven primary schools (Table 2). Most of the projects were based on the theme of reusing and recycling. There was one project intended to instil love for the nature and another one on the issue of pollution. 
Table 2. Sustainability projects carried out in primary schools

\begin{tabular}{|c|c|c|}
\hline Project & Description & Theme \\
\hline Love the Environment & $\begin{array}{l}\text { Aim: } \\
\text { To instil love for the nature among primary school children } \\
\text { Activities: } \\
\text { Fashion Show (using old newspapers) } \\
\text { Watering plants in school compound } \\
\text { Singing 'A Clean Planet' song in English and Mandarin. }\end{array}$ & $\begin{array}{l}\text { Love and care for } \\
\text { nature }\end{array}$ \\
\hline $\begin{array}{l}\text { Miniature Petronas Twin } \\
\text { Tower }\end{array}$ & $\begin{array}{l}\text { Aim: } \\
\text { To highlight the issue of waste plastic bottles pollution } \\
\text { Activity: } \\
\text { Building a miniature Petronas Twin Tower using used plastic bottles }\end{array}$ & Pollution \\
\hline Making compost & $\begin{array}{l}\text { Aim: } \\
\text { Reducing household waste by using leftover food to make compost } \\
\text { Activity: } \\
\text { Making compost from food waste in the school herbal garden }\end{array}$ & Reusing \\
\hline Making pencil holders & $\begin{array}{l}\text { Aim: } \\
\text { Introduce the concept of reusing waste materials to children } \\
\text { Activity: } \\
\text { Student brought used plastic bottles and paper boxes to make into various } \\
\text { shapes of pencil holders }\end{array}$ & Reusing \\
\hline $\begin{array}{l}\text { Recycle bag design } \\
\text { competition }\end{array}$ & $\begin{array}{l}\text { Aim: } \\
\text { Introduce the concept of reusing waste materials to children } \\
\text { Activity: } \\
\text { Student used old shirts to design into recycle bags. Best designs won prizes. }\end{array}$ & Reusing \\
\hline Making recycle bag & $\begin{array}{l}\text { Aim: } \\
\text { Introduce the concept of reusing waste materials to children } \\
\text { Activity: } \\
\text { Student used old shirts to design into recycle bags. }\end{array}$ & Reusing \\
\hline Hanging Garden & $\begin{array}{l}\text { Aim: } \\
\text { Introduce the concept of reusing waste materials to children } \\
\text { Activity: } \\
\text { Used plastic bottles were used to as hanging pots to plant ornamental plants in } \\
\text { school compound }\end{array}$ & Reusing \\
\hline Recycling Campaign & $\begin{array}{l}\text { Aim: } \\
\text { To introduce the concept of recycling at home } \\
\text { Activity: } \\
\text { Students were briefed about upcoming recycling day. Parents helped to being } \\
\text { materials from homes for recycling. Students were guided to segregate wastes } \\
\text { into different categories. }\end{array}$ & Recycling \\
\hline Recycle bins & $\begin{array}{l}\text { Aim: } \\
\text { To start recycling practice in school } \\
\text { Activity: } \\
\text { Install recycle bins for different categories of waster in the school compound. } \\
\text { Recyled materials were collected once a week. }\end{array}$ & Recycling \\
\hline
\end{tabular}

During school visits, supervisors found that these students put in a great deal of time and effort implement sustainability projects. Two exemplary projects are reported in this article. One student demonstrated extraordinary effort to involve K10 to K12 school children in a large-scale recycling project which lasted three days (Figure 8). Parents were involved as well to bring recyclable materials from home to school. This student also engaged the help of many school teachers to organise the students. School children were guided on segregation of wastes into four categories: paper, glass, plastic and aluminium can. Total waste materials of each category were weighed before they were taken away by a recycling company. 

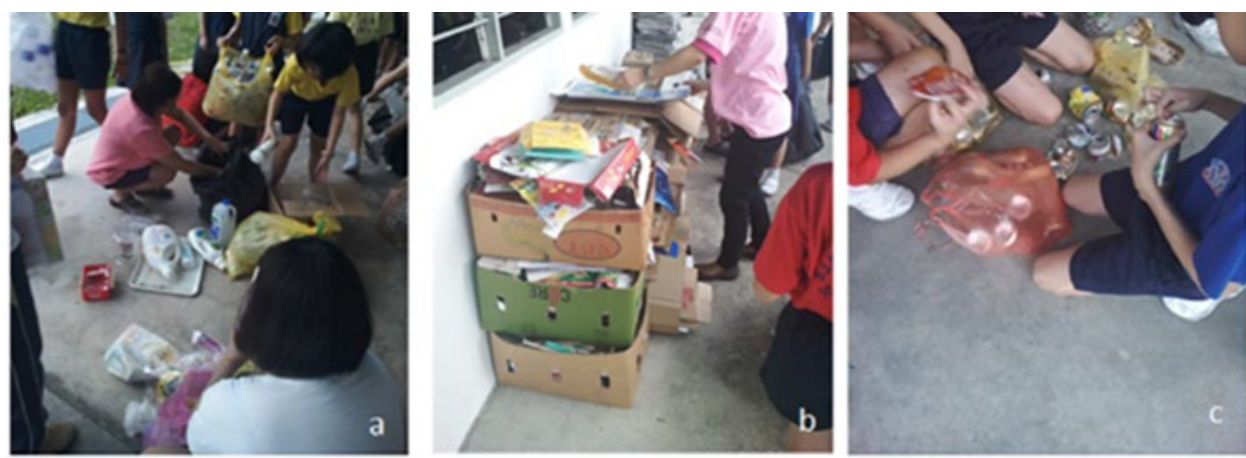

Figure 8. Large-scale recycling project in school. Students sorting out used plastic containers (c). A school teacher helping to stack up collected used papers and boxes (b). Students separating can opener from aluminium can (c).

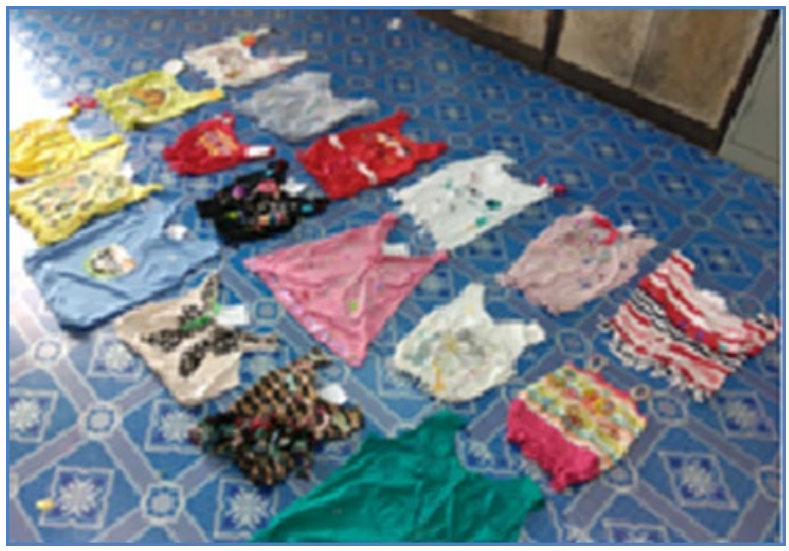

Figure 9. Recycle bags produced by school students

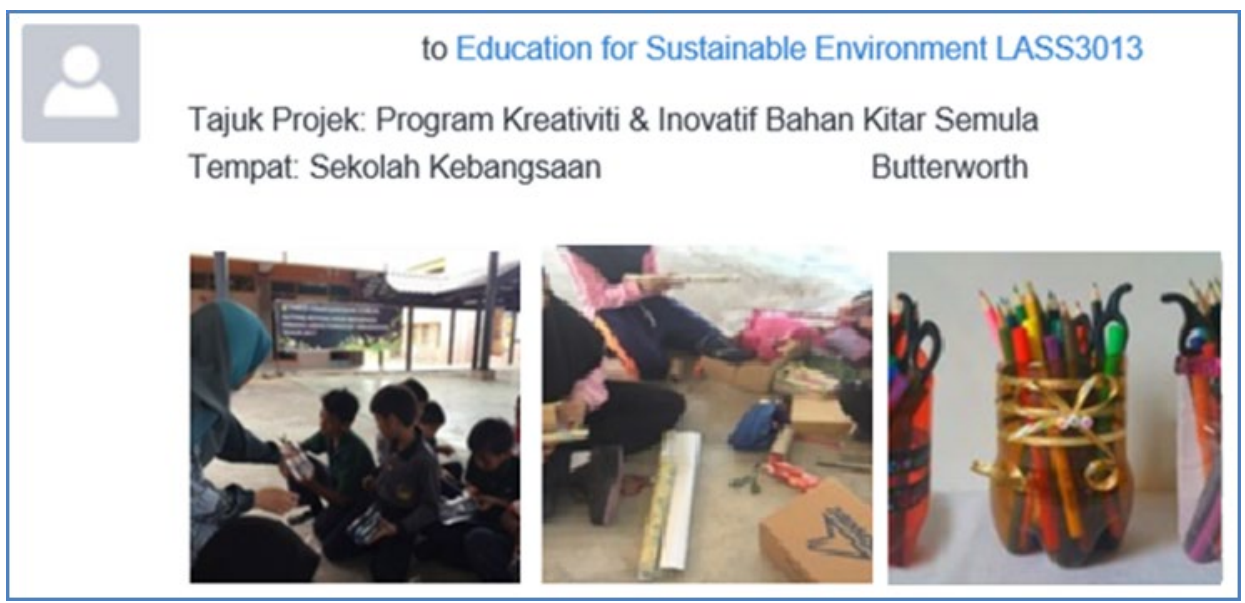

Figure 10. Student shared their project on reusing waste materials on Edmodo

Another student elaborated his sustainability project as a competition for designing recycle bag from used shirts (Figure 9). School children worked in groups to convert used shirts into recycle bags and then decorated them. A total of 56 children took part and design their recycle bags. Parent-teacher association of the school sponsored the prizes which were given to winners during the school assembly.

Since the students were running their sustainability projects in schools during their 12-week teaching practicum in schools, they would hardly have time for face-to-face meet up. To promote sharing of ideas on their projects, students posted pictures of their projects on Edmodo (Figure 10). The use of Edmodo as sharing platform for learning was fared to be very helpful in students' survey results (Figure 11). 


\section{How has Edmodo helped you to share and get ideas and feedback about your sustainability project in school?}

Not helping 0

Helped very little $14 \%$

\section{Helped a lot $86 \%$}

Figure 11. Students' response on the use of Edmodo in their sustainability project in school

How has this course prepared you to be a teacher who is able to educate your students in sustainability?

This course failed to prepare me for the purpose mentioned above. 0

This course helped me a little for the purpose mentioned above. 0 This course was effective in preparing me for purpose mentioned above. $29 \%$

This course has prepared me very well for purpose mentioned above.

$71 \%$

Figure 12. Students' response on how well they were prepared to teach sustainability

\section{Course evaluation}

All students found that the course delivered was effective in preparing them to teach sustainability (Figure 12). Most of them (71\%) claimed that the course has prepared them very well.

\section{Case 2: Teaching Mathematics Incorporating Digital Tools to Promote Sustainability}

In the second case exemplar, teachers were trained in Mathematics digital tools for teaching mathematics (Figure 13). 


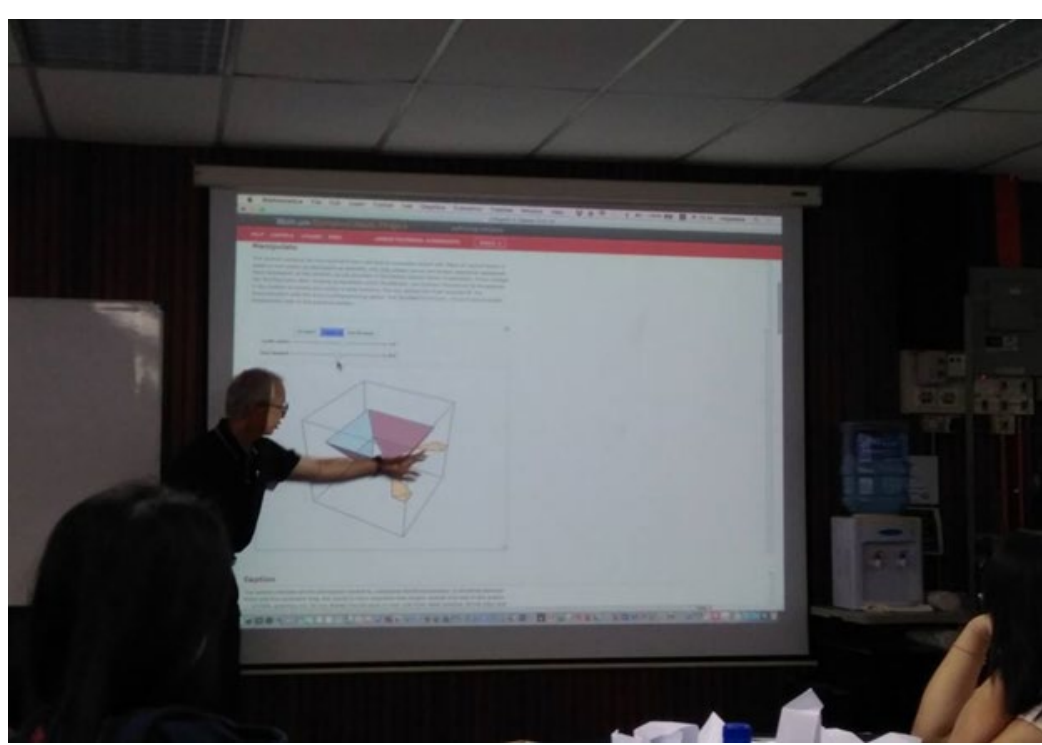

Figure 13. Exemplary technology-enhanced blended-mode mathematics lesson to promote 'Conservation and Wise Use of Resources' (ConWUR)
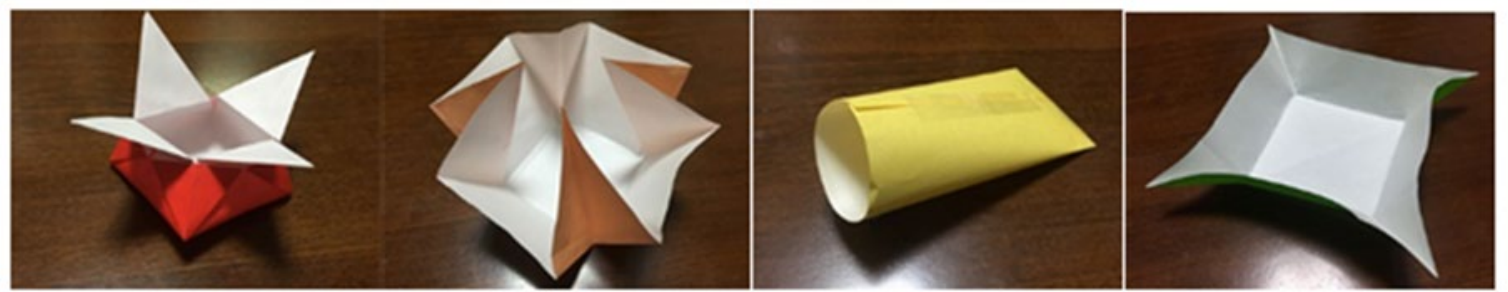

Figure 14. Origami hands-on of cups made by participants using low cost materials

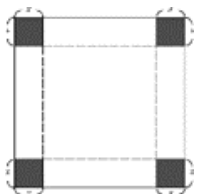

Figure 15. Small squares were cut from four corners of a sheet of paper

Various topics were introduced in the abovementioned in-service training course. In this study, a lesson on 'Origami Cup Problem' (Figure 14) that was introduced during the in-service training workshop in October 2017 will be illustrated. The workshop participants were encouraged to employ critical thinking when they tried to make origami paper cups with the largest possible volume, demonstrating their ability to conserve and use resources wisely.

\section{Example on ‘Origami Cup Problem’ Presented by Workshop Facilitator}

The third co-author who was workshop facilitator taught elementary calculus to $11^{\text {th }}$ grade students in Japan. This experience was shared in the workshop and students were encouraged to use critical thinking skills to create own cups with maximum value of their cup.

The original problem. Small squares of $x \mathrm{~cm} \times x \mathrm{~cm}$ were cut from a sheet of paper (Figure 15) and a rectangular parallelepiped was made (Figure 16). The problem presented was how to maximize the rectangular parallelepiped. This is a typical problem from Japanese textbooks for $11^{\text {th }}$ grade students. The volume is $V=x(12-2 x)^{2}$. Since $\frac{d y}{d x}=12 x^{2}-96 x+144=12(x-2)(x-6)$, the function $\mathrm{V}$ gets the maximal and minimal values when $x=2.6$, and the maximum value $128 \mathrm{~cm}^{3}$ when $x=2$. 


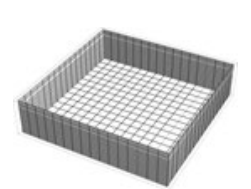

Figure 16. A parallelepiped

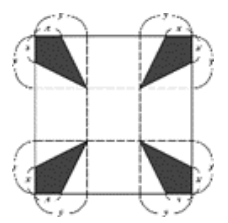

Figure 17. An alternative method to make a an origami cup with maximum volume

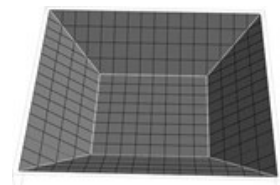

Figure 18. A variant of an origami cup

After the students had solved this problem, they were asked to solve another problem. They were tasked to make a cup that is not a rectangular parallelepiped.

The second variant of the original problem. Students were given a square sheet of paper and a pair of scissors. They were free to make any kind of cup with the maximum volume. Students were very interested in this problem, and made many kinds of cups. Some students tried hard to make a large cup, while others were interested in making a cup with a beautiful shape.

A student proposed the following figure. He cut off four dark gray parts from the paper shown in Figure 17. Then, by folding the remaining paper, he made a rectangular parallelepiped-like object as shown in Figure 18.

\section{DISCUSSION}

For education to be an effective vehicle of social change, teacher education becomes invariably indispensable. Holistic approach in education for sustainable development should take into account how new teachers are being prepared for real-life tasks in school. Regardless of the paradigm shift envisioned in the sustainable development goals, means of its implementation with missing personal and cultural dimensions in teacher education risk ongoing efforts to be external actions of the biophysics world, when in fact what is essentially needed for a lasting change is the shift of consciousness in our inner psychosocial worlds (Rockström et al., 2015). Perhaps with such shift of consciousness, students would not be asked to draw a poster on sustainable consumption for the sake of a competition without appreciating the underlying concept of sustainability. The revision of curriculum delivery methods in this study reflected the need for education for sustainability itself to be transformative, rather than conformative (Sterling, 2016). Teaching and learning strategies used for delivery of curriculum for sustainable development requires transformative approach that is able to raise awareness, provide the knowledge and skills for lasting behavioural change in lifestyle and active participation in social issues with the mindset of societal needs and economic interests placed within the capacity of Earth's life-support system (Griggs, 2013). Blended learning mode enhanced by digital learning platforms illustrated in this study was shown to be effective to promote student engagement in discussion on the learning material provided. Sharing of ideas and feedback between students was facilitated with digital platforms. Furthermore, uploaded learning materials and links to online resources on digital learning platforms advocate the idea of sustainable consumption as hard copies of learning materials was not printed out.

While the eventual teaching practice of the future teachers involved in this study can only be determined in a longitudinal study, teacher education programmes for environmental and sustainability education should consider a complementary relationship between the goal-oriented view of education and ESD and the leaner-centred view of education and ESD (Sterling, 2011). The learner-centred view places importance on the process of learning in order to empower learners to be critical, reflective and autonomous. On the other hand, the extrinsic goal-oriented view of education emphasizes on the exigency of global context that necessitates the corresponding behavioural change. Embracing both the learner-centred and goal-oriented views should ideally result in shift of educational 
thinking that can be translated into transformative teaching and learning to effect change for planetary well-bring as emphasized in the SDG agenda.

\section{CONCLUSION}

Student-centred blended learning comprising integration of face-to-face lectures, presentations, games and school project on online learning platforms in this study offer promising alternatives to prepare future teachers with knowledge, awareness and skills needed for education in sustainable living (Makrakis \& Kostoulas-Makrakis, 2012). The use of e-platforms and digital tools are also found to be effective to promote sharing, exchange and dissemination of information before, during and after the events (as illustrated in screenshots of Case $\mathbf{1}$ and Case $\mathbf{2}$ in Appendix). Hence more efforts to promote ESD in pre-/in-service teacher education supported by digital tools and e-platform should be implemented continuously.

Content and strategies of blended learning in this study could serve as the basis of transformative learning which focus on learning-based change, involving 'learning to $\mathrm{know}^{\prime}$, 'learning to do', 'learning to live together' and 'learning to be.' Having learnt the strategies for ESD at teacher education institute, these future teachers need to integrate ESD across school subjects. Teacher education needs to reflect a reassuring level of commitment, inventiveness and fortitude to empower teachers to make a positive difference in their spheres of influence. The outcome of teacher education should be one that can manifest a culture of critical commitment to make a significant contribution in social-ecological resilience and sustainability (Sterling, 2016). Subsequently, young minds within the sphere of teachers' influence can be reaffirmed with human values such as dignity, empathy, passion and kindness to reinvigorate a humanistic approach towards sustainability.

\section{LIMITATIONS AND SUGGESTIONS}

Successful researchers must be consistent with their practices, showing integrity and genuine interest to help with long-term plans of collaboration with sample institutions. This study was only limited to two institutions that exemplify how ESD could be promoted in pre-service and in-service teacher education programmes integrating ICT within the constraints of time, study schedules and resources available. If opportunity and time permit, more similar studies could be replicated to more samples in other institutions to reach out to wider audiences people including the marginalized towards flexible 'Education for All' (EFA) with more exchange of ideas, sharing of exemplary practices as well as meaningful results analysed through mixed-method approaches.

As Malaysia needs increased number of skilled workers in science and technology to achieve the goals of Vision 2020 (that was recently postponed to 2025 due to the economic situation faced in Malaysia), i.e. to achieve a fully industrialized society in Malaysia. This will include those skilled in the management of science and technology activities, as well as technicians, engineers and researchers who could initiate and maintain industrial development (Abdul Razak, 2005). In fact national research showed that those possessing such skills are not available in sufficient numbers to provide for current activities, let alone for future requirements, despite the current rapid levels of growth and consequent buoyancy in the market for science and technology skilled labour (Lee, Yoong, Zon, Ghazali, \& Lim, 1996; MASTIC, 1994). Hopefully more research could be conducted integrating ICT with subsequent activities aim to promote national innovation eco-system in line with the National Innovation Strategy (NIS).

\section{REFERENCES}

Abdul Razak, D. (2005). Closing Remarks during "Regional Workshop on Education for Sustainable Development" organized by Corporate Development Division, USM and UNU/Institute of Advanced Studies (UNU/IAS). April 11-13, 2005 at International Organizations Centre, USM. Penang: Universiti Sains Malaysia.

Balasubramaniam, K., Jaykumar, V., \& Fukey, L.N. (2014). A study on student preference towards the use of Edmodo as a learning platform to create responsible learning environment. Procedia - Social and Behavioral Sciences, 144, 416-422. https:/ / doi.org/10.1016/j.sbspro.2014.07.311

Bonk, C. J., \& Graham, C. R. (2006). The Handbook of Blended Learning: Global Perspectives, Local Designs. San Francisco, CA, USA : Pfeiffer Publishing.

Brandtzæg, P. B., \& Heim, J. (2007). Initial context, user and social requirements for the Citizen Media applications: Participation and motivations in off- and online communities. Citizen Media Project. Retrieved on June 20, 2017 from http:/ / onlinelibrary.wiley.com/doi/10.1111/j.1083-6101.2012.01580.x/full.

Coll, S. D., \& Coll, R. K. (2017) Using blended learning and out-of-school visits: pedagogies for effective science teaching in the twenty-first century, Research in Science \& Technological Education, 36(2), 185-204. https:/ / doi.org/10.1080/02635143.2017.1393658 
Cronbach, L. J. (1982). Prudent aspirations for social inquiry. In W.H. Kruslkal (Ed.), The social sciences: Their nature and uses. Chicago: Univ. of Chicago Press.

Davis, R. (2009). Facebook. The Electronic Journal for English as a Second Language. Retrieved on June 23, 2017 from http:/ / www.tesl--ej.org/wordpress/issues/volume13/ej51/ej51m1/

Garrison, D. R., \& Kanuka, H. (2014). Blended learning: Uncovering its transformative potential in higher education. Internet and Higher Education, 7, 95-105. https:// doi.org/10.1016/j.iheduc.2004.02.001

Griggs, D. (2013, March 21). Sustainable development goals for people and planet. Nature, 495, 305-307. https:// doi.org/10.1038/495305a

Heterick, B., \& Twigg, C. (2003, February). The Learning MarketSpace. Retrieved on December 5, 2003, from http:/ / www.center.rpi.edu/LForum/LM/Feb03.html

Holland, C., \& Muilenburg, L. (2011). Supporting Student Collaboration: Edmodo in the Classroom. In M. Koehler \& P. Mishra (Eds.), Proceedings of SITE 2011--Society for Information Technology \& Teacher Education International Conference (pp. 3232-3236).

Jarc, J. (2010). Edmodo-a free, web 2.0 classroom management tool. Retrieved on August 24, 2010, from http:/ / trendingeducation.com/?p=190

Lee, M. N. N., Yoong, S., Zon, K., Ghazali, M., \& Lim, C. S. (1996). Students' orientation towards science and mathematics: Why are enrolments falling? USM, Penang: School of Educational Studies (SES).

Makrakis, V., \& Kostoulas-Makrakis, N. (2012). Course curricular design and development of the M.Sc. Programme in the field of ICT in education for sustainable development. Journal of Teacher Education for Sustainability, 14(2), 5-40. https:/ / doi.org/10.2478/v10099-012-0007-7

MASTIC (1994). Science and Technology Awareness among Secondary School Students. Ministry of Science, Technology and the Environment (MOSTE) Malaysia: Malaysian Science and Technology Information Centre (MASTIC).

Meyer, K. A. (2003). Face-to-face versus threaded discussions: The role of time and higher-order thinking. Journal of Asynchronous Learning Networks, 7(3), 55-65.

Patton, M. Q. (1990). Qualitative evaluation and research methods (2nd ed.), Newbury Park: Sage Pubs.

Rockström, J. W. (2015). Bounding the planetary future: Why we need a great transition. Boston, MA: Tellus Institute. Retrieved $30 \quad$ March 2018, from http://www.tellus.org/pub/RockstromBounding_the_Planetary_Future.pdf

Sarmiento, C. Q. S. (2005). Becoming a qualitative researcher. Paper presented and compiled in the Proceedings for the $3^{\text {rd }}$ Qualitative International Conference (August 21 to 23, 2005), UiTM, Johor Bharu, Malaysia.

Siraj, S., Azman, M. K., \& Hussin, Z., (2013). Effectiveness of Facebook Based Learning to Enhance Creativity among Islamic Studies Students by Employing Isman Instructional Design Model. Turkish Online Journal of Educational Technolog, 12, 60-67.

Starkey, L. (2010). Teachers' pedagogical reasoning and action in the digital age. Teachers and Teaching, 16(2), 233244. https:/ / doi.org/10.1080/13540600903478433

Steffe, L. P., \& Gale, J. (Eds.) (1995). Constructivism in Education. Lawrence Erlbaum Associates, New Jersey.

Sterling, S. (2011). Learning for resilience, or the resilient learner?: Towards a necessary reconciliation in a paradigm of sustainable education. In M. Krasny, C. Lundholm \& R. Plummer (eds), Resilience in social-ecological systems: The role of learning and education (pp. 511-528). London: Routledge.

Sterling, S. (2016). A commetary on education and sustainable development goals. Journal of Education for Sustainable Development, 10(2), 208-213. https:/ / doi.org/10.1177/0973408216661886

Vygotsy, L. S. (1978). Mind in Society: The Development of Higher Psychological Processes. Cambridge, MA: Harvard University Press.

Wenger, E. (1998). Communities of Practice: Learning, Meaning, and Identity. London: Pinter. https://doi.org/10.1017/CBO9780511803932

Witherspoon, A. (2011) Edmodo... A Learning Management System. Retrieved from http:/ / www.plugintotechnology.com/2011/01/edmodoa -learningmanagement.html

Yin, R. K. (1994). Case study research: Design and methods (2nd ed.), Thousand Oaks, CA: Sage Publications. 


\section{APPENDIX}

Wise use of digital tools for sharing and exchange before, during and after workshops

Case 1: ESD course for Pre-service Teachers as disseminated in Edmodo e-platform

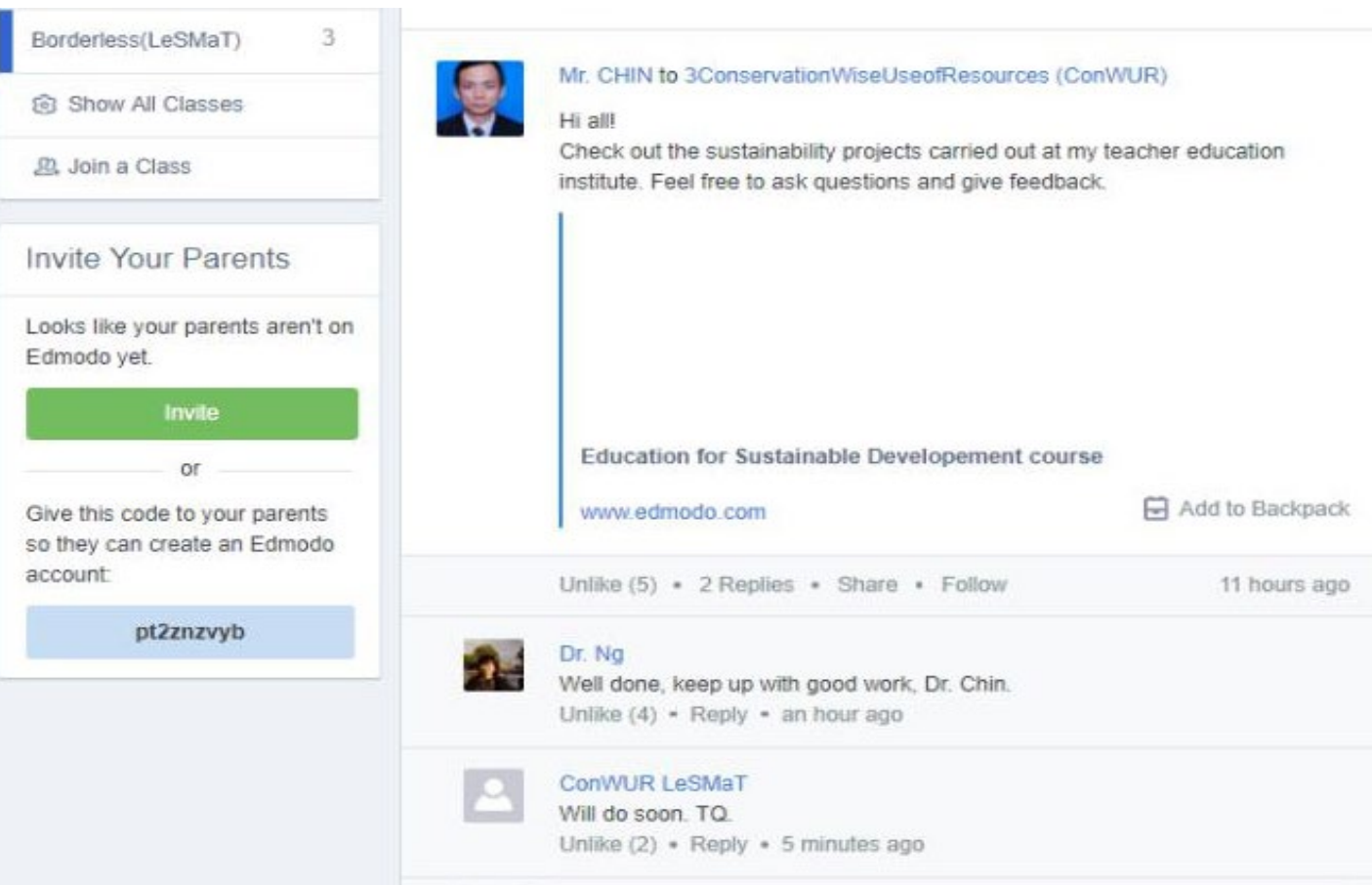

Case 2: Use of social learning platform to disseminate information and sharing/exchange
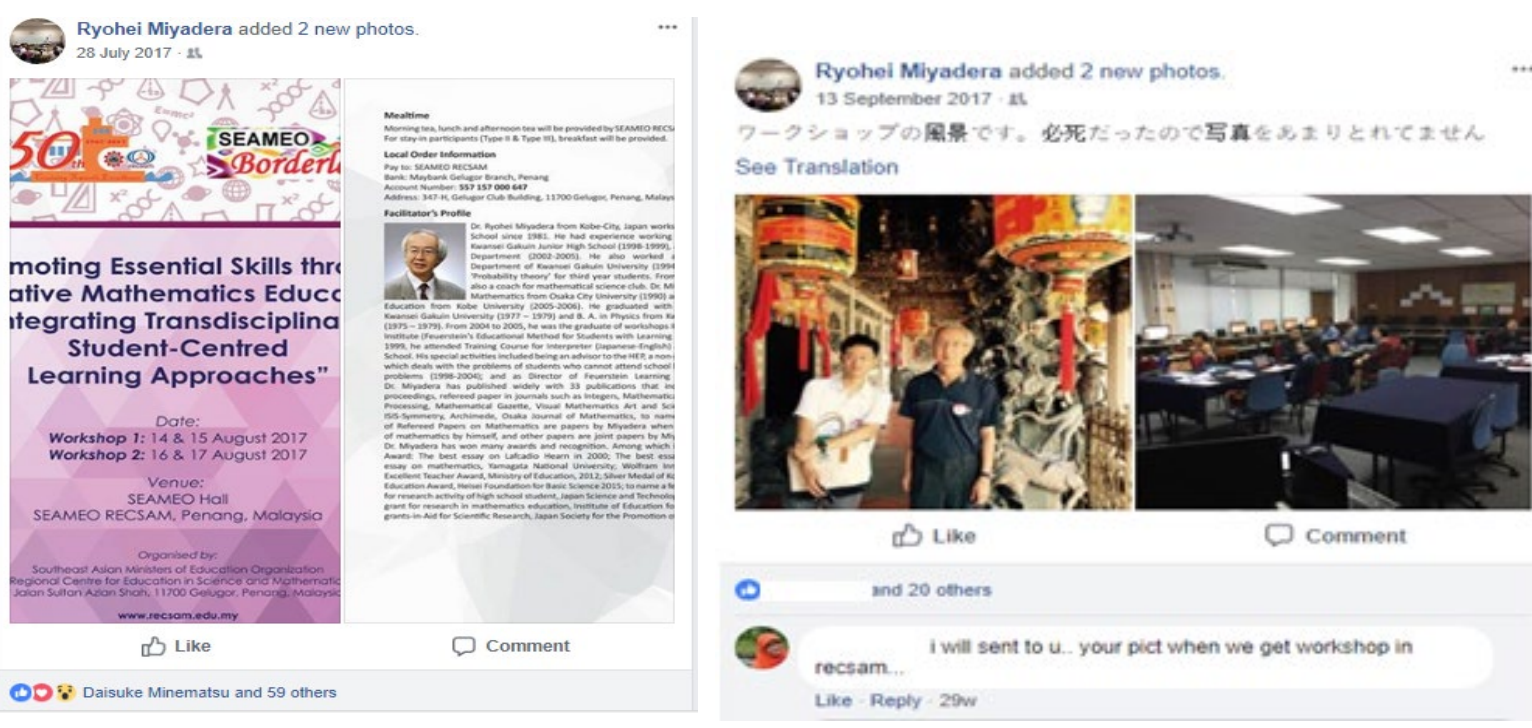

http://www.ejmste.com 